\title{
TRANSIENT ANALYSIS IN PWM INVERTER BASED ON TWO DIMENSIONAL LAPLACE TRANSFORM
}

\author{
I.Ye. Korotyeyev ${ }^{1^{*}}$, M. Klytta ${ }^{2 * *}$ \\ 1 - University of Zielona Góra, Institute of Electrical Engineering, \\ Podgórna, 50, 65-246 Zielona Góra, Poland, \\ e-mail: I.Korotyeyev@iee.uz.zgora.pl \\ 2 - University of Applied Sciences Mittelhessen, Department of Electrotechnics and Information Technology, \\ Wiesenstrasse, 14, 35-390 Giessen, Germany, \\ e-mail: Marius.Klytta@ei.thm.de
}

An analysis of transient and steady-state behaviours in PWM inverter circuits is connected with a calculation of processes with different frequencies. In order to analyze such systems an extension of ordinary differential equations with one time variable to partial differential equations with two time variables is used. The solution of a resulting partial differential equation is obtained by using the two-dimensional Laplace transform. The finding of a transient process is connected with the necessity of residuum calculation for part of poles. This feature depends on choose of a part of plane of the independent variables. An expression for a transient process is obtained for different intervals of voltage supply. References 3, figures 4.

Key words: transient process analysis, two dimensional Laplace transform.

Introduction. Processes in inverters with pulse-width modulation (PWM) are considered in different works. One of the often used circuits is a single phase half bridge DC-AC inverter shown in Fig. 1. Forming of harmonic output signals can be obtained by comparing a high frequency sawtooth ramp voltage with a low-frequency sinusoid of the wished harmonic.

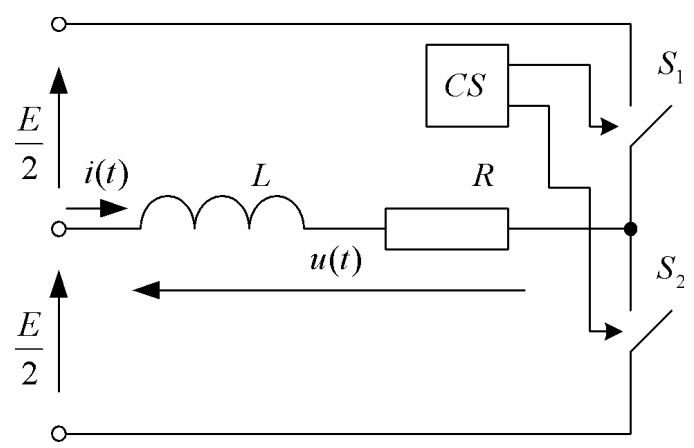

Fig. 1

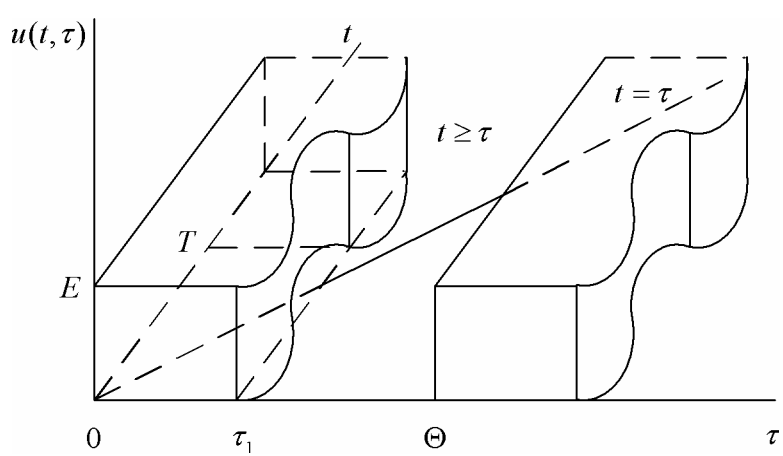

Fig. 2

In order to analyze a voltage in the inverter a method based on double Fourier series [1] is applied. An extension of differential equations with one independent variable of time $t$ to equations with two independent variables of time $t$ and $\tau$ [2] is used for determine a periodic steady-state behavior in circuits of an inverter.

For exploration of all processes in the circuit of the inverter it is also important to investigate a transient process. For the system with two time variables the two-dimensional Laplace transform should be applied. Using the two-dimensional Laplace transform there are specificity in obtaining both components: the steady-state and the transient behavior. In regards to finding the steady-state behavior a procedure is based on residues calculation with respect to poles of a supply voltage and control system. In case of the transient process a different procedure should be applied.

In this article a procedure directed to find the transient process for systems described by differential equations with two time variables will be shown. In order to find the transient process, the two dimensional Laplace transform is used. The problem based on finding boundary conditions is considered and the second based on using the two dimensional Laplace transform is presented. Originals are found only to parts of poles of Laplace transform. In the next step, expressions for the transient current in a $R-L$ load is determined.

Mathematical model. The switches $S_{1}$ and $S_{2}$ shown in Fig. 1 are ideal, turned on and off alternately according to control signals. Processes in the circuit are described by the differential equation 


$$
L \frac{d i(t)}{d t}=-R i(t)+u(t),
$$

where $i(t)$ is a current, $u(t)$ is a voltage on the output of the inverter.

Since the voltage $u(t)$ is periodical, as shown in Fig. 2, therefore it is possible to find processes in the $R-L$ load by the extension of the differential equation (1) with one independent variable of time $t$ to the equation with two independent variables of time, i.e. $t$ and $\tau$ [2]

$$
L \frac{\partial i(t, \tau)}{\partial t}+L \frac{\partial i(t, \tau)}{\partial \tau}=-R i(t, \tau)+u(t, \tau) .
$$

We solve the differential equation (2) using use the two-dimensional Laplace transform [3]

$$
F(s, q)=\int_{0}^{\infty} \int_{0}^{\infty} f(t, \tau) e^{-s t-q \tau} d \tau d t .
$$

Using this transform to (2) yields

$$
L(s+q) I(s, q)=-R I(s, q)+L I(s, 0)+U(s, q),
$$

where $U(s, q)$ and $I(s, q)$ are images of the voltage $u(t, \tau)$ and current $i(t, \tau)$. In (3) we assume that initial condition is $i(0, \tau)=0$.

A solution of such an equation takes the form

$$
I(s, q)=\frac{E}{s q[L(s+q)+R]}+\frac{L I(s, 0)}{L(s+q)+R},
$$

where $U(s, q)=E /(s q)$ in the interval $0 \leq \tau \leq \tau_{1}, \tau_{1}=\sigma+K \cos \omega t, \sigma$ is an average value of a modulating signal, $K$ is an amplitude of a modulating signal, $I(s, 0)$ is an image of the current $i(t, 0)$, $\omega=2 \pi / T$. It should be noted that $\sigma \leq \Theta / 2$.

In order to find an original to (4) we should select the appropriate region of the plane $(t, \tau)$. For the part of the plane $(t, \tau)$ with $t \geq \tau$ a transient process is founded by calculation of the residues at the points

which for the interval $0 \leq t \leq \tau_{1}$ yields

$$
q=-s-R / L, \quad s=0, \quad q=0,
$$

$$
i(t, \tau)=e^{-\frac{R}{L} \tau} i(t-\tau, 0)+\frac{E}{R}\left(1-e^{-\frac{R}{L} \tau}\right) .
$$

For the interval $\tau_{1} \leq \tau \leq \Theta$ the voltage $u(t, \tau)=0$, therefore a transient process has the form

$$
i(t, \tau)=i\left(t-\tau, \tau_{1}\right) e^{-\frac{R}{L}\left(\tau-\tau_{1}\right)} .
$$

Substituting the boundary condition in the result (6) one obtains the following expression

$$
i\left(t^{*}, \tau^{*}\right)=e^{-\frac{R}{L}\left(\tau^{*}-\tau^{\prime}\right)}\left[\frac{E}{R}\left(1-e^{-\frac{R}{L} \tau^{\prime}}\right)\right] .
$$

In this expression $\tau^{\prime}$ determinates as a result of solving the equation $\sigma+K \cos \omega t^{\prime}=t^{\prime}-\left(t^{*}-\tau^{*}\right)$ and $\tau^{\prime}=\sigma+K \cos \omega t^{\prime}$ as shown in Fig. 3. This is connected with the fact that the argument of the boundary condition $i(t-\tau, 0)$ is the difference of two time variables $t$ and $\tau$.

Results of calculation. Let us calculate the transient process for following parameters: $R=1,1 \Omega ; \quad L=0,9 \mathrm{mH} ; E=100 \mathrm{~V}$; $T=20 \mathrm{~ms} ; \Theta=T / 100 \mathrm{~ms} ; K=0,1 \Theta \mathrm{ms} ; \sigma=\Theta / 2 \mathrm{~ms}$. In the first interval $0 \leq \tau \leq \tau_{1}$ the current $i(0, \tau)=0$. The time waveform of the transient process for $0 \leq \tau \leq 2 \Theta$ is shown in Fig. 4 .



Fig. 3 




Fig. 4

It should be noted that a transient current in the circuit of the inverter can be obtained by equating $t=\tau$. In order to check the obtained results a numerical method is used. This comparing shows correspondence between both calculation results.

Conclusions. In this paper the procedure for finding transient processes in circuits of an inverter with a sinusoid PWM control has been presented. The procedure takes into account that finding of the transient behaviour could be considered either for $t \geq \tau$ or for $\tau \geq t$ part of the $(t, \tau)$ plane. The boundary conditions correspond for $i(t-\tau)$ or $i(\tau-t)$ with difference arguments. This defines the procedure of the residues calculation and use of the boundary conditions. The obtained results have been compared with results obtained by the numerical calculation of this transient process. It showed correspondence of both results.

1. Holmes D. Grahame, Lipo Thomas A. Pulse width modulation for power converters. Theory and practice. IEEE Press Series on Power Engineering. Hoboken, NJ: John Wiley, 2003. 744 p.

2. Korotyeyev I., Zhuikov V., Kasperek R. Electrotechnical systems. Calculation and analysis with Mathematica and PSpice. London: CRC Press, 2010. 256 p.

3. Ditkin V.A., Prudnikov A.P. Operational Calculus in Two Variables and its Application. London: Pergamon Press, 1962. 167 p.

УДК 621.314

І.С. Коротсєв ${ }^{1}$, М. Клитта ${ }^{2}$

1 - Зеленогурський університет, Інститут промислової електроніки,

вул. Подгурна, 50, 65-246, Зелена Гура, Польща

2 - Міттелхессенський університет прикладної науки,

вул. Весенстрассе, 14, 35-390, Гіссен, Німеччина

АНАЛІЗ ПЕРЕХІДНОГО ПРОЦЕСУ В ІНВЕРТОРІ 3 ШІМ НА БАЗІ ДВОВИМІРНОГО ПЕРЕТВОРЕННЯ ЛАПЛАСА

Аналіз перехідних і встановлених режимів у ланцюггах інвертора з ШІМ пов'язаний з розрахунком процесів 3 різними частотами. Для аналізу таких систем застосовується процедура розширення від диференціальних рівнянь з однією змінною часу до диференціальних рівнянь з частковими похідними (у часткових похідних) $i$ двома змінними часу. Розв'язок диференціального рівняння в часткових похідних знаходиться із використанням двовимірного перетворення Лапласа. Пошук перехідного прочесу пов'язаний з необхідністю обчислення відрахувань для частини полюсів. Ця властивість залежить від вибору частини площини незалежних змінних. Вираз для перехідного прочесу отримано для різних інтервалів напруги живлення. Бібл. 3, рис. 4.

Ключові слова: аналіз перехідного процесу, двовимірне перетворення Лапласа.

УДК 621.314

И.Е. Коротеев ${ }^{1}$, М. Клитта ${ }^{2}$

1 - Зеленогурский университет, Институт промышленной электроники,

ул. Подгурная, 50, 65-246, Зеленая Гура, Польша.

2 - Миттелхессенский университет прикладной науки,

ул. Весенстрассе, 14, 35-390, Гиссен, Германия

АНАЛИЗ ПЕРЕХОДНОГО ПРОЦЕССА В ИНВЕРТОРЕ С ШИМ НА ОСНОВЕ ДВУМЕРНОГО ПРЕОБРАЗОВАНИЯ ЛАПЛАСА

Анализ переходных и установившихся режимов в цепях инвертора с ШИМ связан с расчетом процессов с различными частотами. Для анализа таких систем применяется процедура расширения дифференциальных уравнений с одной переменной времени до дифференциальных уравнений с частными производными и двумя переменными времени. Решение дифференциального уравнения в частных производных находится с помощью двумерного преобразования Лапласа. Нахождение переходного процесса связано с необходимостью вычисления вычетов для части полюсов. Это свойство зависит от выбора части плоскости независимых переменных. Получено выражение для переходного процесса для разных интервалов питающего напряжения. Библ. 3 , рис. 4. Ключевые слова: анализ переходного процесса, двумерное преобразование Лапласа. 